\title{
Iron stores and coagulation parameters in patients with hypoxemic polycythemia secondary to chronic obstructive pulmonary disease: The effect of phlebotomies
}

From the Respiratory and Hematology Divisions, Universidade Federal de São Paulo/Escola Paulista de Medicina São Paulo, Brazil.

This study was designed to determine the effects of phlebotomy on iron body contents and coagulation tests of COPD patients with polycythemia secondary to hypoxemia. Seventeen patients with COPD and hematocrits higher than 54 percent (mean Hct: $57 \pm 0.49$ percent ), who had not received anti-inflammatory or antiplatelet aggregation agents recently. Their mean forced expiratory volume at 1 second $\left(F E V_{1}\right)$ was $0.92 \pm 0.11 \mathrm{~L}$. Intervention: Blood work was collected to evaluate the following: serum iron and ferritin levels, total iron binding capacity, transferrin saturation index, fibrinogen plasma levels, activated partial thromboplastin time, platelet count, platelet aggregation measurements, and thromboelastography coagulation parameters. The blood samples were obtained before and about 7 days after the hematocrit correction by $300-400 \mathrm{ml}$ phlebotomies done every other day. The mean number of phlebotomies done for each patient was 4.4. Postphlebotomy iron serum levels decreased from $90.1 \pm 14.8$ to $59.7 \pm 9.9 \mathrm{mg} / \mathrm{dl}$ and the ferritin serum levels from $133.8 \pm 37.9$ to $70.8 \pm 32.7 \mathrm{ng} / \mathrm{ml}(\mathrm{p}<0.05)$. Regarding the coagulation studies, there were significant increases in the platelet count, from $227,300 \pm 13,900$ to $312,500 \pm 30,200$ per $\mathrm{mm}^{3}$, and in the maximum clot amplitude (a) obtained by thromboelastography ( from $53.6 \pm 1.4$ percent to $60.4 \pm 1.1$ percent). The coagulation time (k) of the thromboelastography also decreased significantly, from $7.5 \pm 0.7 \mathrm{~mm}$ prephlebotomy to $4.5 \pm 0.3 \mathrm{~mm}$ postphlebotomy. Although the coagulation changes were small amount, the observed significant decrease in iron contents may have important clinical implications.

UNITERMS: Secondary polycythemia; repetitive phlebotomies; iron deficiency; coagulation; chronic obstructive pulmonary disease

\section{INTRODUCTION}

B loodlettings, or phlebotomies, are still advocated in the care of chronic obstructive pulmonary disease (COPD) patients with cor pulmonale and severe secondary polycythemia. ${ }^{1}$ Several authors have shown that hematocrit (Hct) reductions in hypoxemic patients with COPD and polycythemia are followed by improvement in general symptoms, ${ }^{2-5}$ mental activity ${ }^{2-6}$ and exercise performance. ${ }^{2-4.7 .8}$

\section{Address for correspondence:}

José A. B. Martinez MD

Disciplina de Pneumologia (Lung Division) UNIFESP/EPM

Rua Botucatu, 740 - Vila Clementino

São Paulo/SP - Brasil - CEP 04023-900
In a group of patients performing exercise studies in ergometer, the maximum workload and oxygen consumption have increased 31 and 16 percent respectively, when the mean Htc had decreased from 62 to 50 percent. ${ }^{8}$ These effects are not secondary to changes in respiratory mechanics or blood gases..$^{2.45 .7-10}$ Rather, it seems they result from improvements in hemodynamic conditions related to a better blood viscosity. ${ }^{3.11-13}$

Although a great deal has been published in this field, no attention has been paid to the potential hematological consequences of phlebotomies. Similarly to what happens with blood donors and during the treatment of hemochromatosis, repeated phlebotomies in COPD patients could lead to reductions in their iron body contents. ${ }^{14.15}$ Iron deficiency states may run with decrements in work performance secondary to drops in 
hemoglobin levels, and disturbances in muscular oxidative metabolism. ${ }^{16}$ In the case of reductions in iron body contents actually developing in COPD patients following phlebotomies, the former could act as limiting factors for expected exercise improvements.

In addition, polycythemia is a well known risk factor for thrombosis, ${ }^{17}$ and many studies suggest that COPD patients have a higher tendency to have thromboembolic episodes. ${ }^{18-20}$ Some studies of thrombotic risk in COPD have shown an increased tendency towards coagulation with altered values in the thromboelastogram, hyperfibrinogemia and increased platelet aggregation. ${ }^{18.21-23}$ Therefore, we hypothesized that a reduction in Hct levels by phlebotomies could also have a favorable effect on decreasing such thrombotic risk.

The present study investigates the effects of the Hct correction by repeated phlebotomies on parameters of hemostasis and body iron contents in COPD patients with severe secondary hypoxemic polycythemia.

\section{PATIENTS AND METHODS}

\section{Patient Selection}

Seventeen with COPD and polycythemia ( Hct 54 percent or more) patients were studied after signing an informed consent form. All patients were in stable respiratory conditions, without clinical evidence of right or left ventricular failure. They had not been under any antiplatelet or anti-inflammatory agent for at least the prior 10 days, and during the study period there were no changes in their daily medications. None of the patients showed clinical evidence of blood loss or were using oxygen at that time.

Following an initial laboratory evaluation, phlebotomies of 300 to $400 \mathrm{ml}$ were performed every other day until a venous Hct value around 45 percent was reached (range: 41 48 percent). A second set of laboratory tests was then performed about 7 days after the last phlebotomy session.

\section{Iron Stores Measurements}

Venous blood samples with no anticoagulant were collected from fasting patients in the morning. Iron serum levels and serum total iron binding capacity (TIBC) were measured using a commercially available kit (Iron Roche ${ }^{\circledast}$ ) with readings made with a Coleman $6 / 20$ spectrophotometer. Ferritin serum levels were also evaluated by a commercially available enzymatic immunoassay (Ferrizyme $\mathrm{TM}^{\otimes}$ - Abbot Laboratories). The transferrin saturation index (TSI) was calculated as the percentile ratio between serum iron levels and TIBC.

\section{Coagulation Studies}

Coagulation tests were performed on 3.8 percent sodium citrate venous blood samples collected simultaneously with the iron blood work. The following determinations were made:

- Activated partial thromboplastin time (APTT) using human cephalin. ${ }^{24}$ The results were expressed as the ratio to the control values for the laboratory on that day.

- Fibrinogen plasma levels, assessed by the RatnoffMenzie method. ${ }^{25}$

- Platelet count, made in an automatic counter Clay Adams model Ultra-Flo.

- Platelet aggregation determinations by the Born method in a Chronolog aggregometer ${ }^{26}$ The aggregation agents ADP in concentrations of $1 \mathrm{mM}$ and $3 \mathrm{mM}$, epinephrine at 1:1000 dilution, and human collagen were used in samples from each patient. The percentage of aggregated platelets was calculated at a curve point corresponding to an interval of 5 minutes from the initial stimulus for each aggregation agent.

- Thromboelastography (TEG), using a Hartert thromboelastograph made by Hellige. This test examines the entire blood coagulation process and the interaction of all involved components. ${ }^{27}$ The reaction time $\boldsymbol{r}$, the coagulation time $k$, and the maximum clot amplitude $a$, were measured using a special ruler on the developed film.

\section{Statistical Methods}

All data are expressed as the mean \pm standard error. The Wilcoxon test was used in the statistical analysis for the nonindependent variables. A level of 5 percent was fixed as the limit for rejection of the null hypothesis.

\section{RESULTS}

Thirteen male and four female patients were studied. Most of them had severe or moderate COPD with arterial hypoxemia (Table 1). The mean Hct fell from 57 percent before phebotomies to 45 percent at the time of the final 
Table 1

Patient Summary

\begin{tabular}{lccccccc}
\hline & & $\mathrm{Age}$ & $\mathrm{FEV}$ & $\mathrm{FVC} / \mathrm{FEV}$ & $\mathrm{PaO}_{2}$ & $\mathrm{Hct}$ Pre & Hct Post \\
No. & Gender & $\mathrm{yr}$ & $\mathrm{L}$ & $\%$ & $\mathrm{mmHg}$ & $\%$ \\
\hline 1 & $\mathrm{M}$ & 53 & 1.17 & 50 & 47 & 54 & 45 \\
2 & $\mathrm{M}$ & 44 & 0.82 & 38 & 39 & 55 & 48 \\
3 & $\mathrm{M}$ & 60 & 0.71 & 35 & 44 & 54 & 44 \\
4 & $\mathrm{M}$ & 63 & 0.59 & 31 & 49 & 57 & 45 \\
5 & $\mathrm{M}$ & 44 & 0.65 & 38 & 45 & 60 & 45 \\
6 & $\mathrm{~F}$ & 36 & 0.47 & 47 & 42 & 57 & 41 \\
7 & $\mathrm{M}$ & 50 & 1.46 & 50 & 46 & 63 & 44 \\
8 & $\mathrm{~F}$ & 72 & 0.48 & 45 & 38 & 56 & 46 \\
9 & $\mathrm{M}$ & 28 & 0.57 & 36 & 42 & 58 & 47 \\
10 & $\mathrm{M}$ & 75 & 1.19 & 45 & 49 & 60 & 47 \\
11 & $\mathrm{M}$ & 67 & 1.41 & 60 & 53 & 58 & 44 \\
12 & $\mathrm{M}$ & 70 & 1.68 & 60 & 51 & 55 & 45 \\
13 & $\mathrm{~F}$ & 42 & 0.65 & 32 & 46 & 56 & 43 \\
14 & $\mathrm{~F}$ & 68 & 0.44 & 37 & 49 & 58 & 44 \\
15 & $\mathrm{M}$ & 70 & 0.62 & 35 & 53 & 57 & 46 \\
16 & $\mathrm{M}$ & 35 & 1.88 & 49 & 52 & 55 & 45 \\
17 & $\mathrm{M}$ & 66 & 0.93 & 28 & 59 & 55 & 42 \\
\hline Mean & - & $55 \pm 3.6$ & $0.92 \pm .11$ & $42 \pm 2.4$ & $47 \pm 1.2$ & $57 \pm .49$ & $45 \pm .49$ \\
\hline
\end{tabular}

studies. The second set of blood tests were collected $8.7 \pm$ 1.3 days after the last phlebotomy. The time between blood collection and actual sample analysis was no longer than two hours in every case.

\section{Iron Measurements}

There were significant decreases in the serum levels of iron, ferritin and TSI postphlebotomy (Table 2). Twelve patients ( 70 percent) showed a decrease in iron concentrations and in 7 of these it remained below 50 percent of the initial value. Falls in ferritin levels were seen in 16 patients (94 percent). Such decreases were greater than 50 percent from the baseline values in 12 (70 percent) of the subjects. In 8 patients ( 47 percent), the final ferritin values were below $10 \mathrm{ng} /$ $\mathrm{ml}$, indicating severe iron depletion (Fig. 1).

\section{Coagulation Studies}

Coagulation studies obtained before and after phlebotomies are listed in Table 3 . All the initial mean values were within the normal limits of the authors' laboratory except for the $\boldsymbol{r}$ parameter of the TEG, which was slightly increased. No significant decreases were seen in the mean APTT and fibrinogen levels after phlebotomies. The platelet count significantly increased from $227,300 / \mathrm{mm}^{3}$ to $312,000 / \mathrm{mm}^{3}$ after the procedure. Fifteen patients ( 88.2 percent) showed an increase in the

\begin{tabular}{lccc}
\hline \multicolumn{4}{c}{$\begin{array}{c}\text { Table } 2 \\
\text { Iron contents measurements (Mean } \pm \text { SE) obtained } \\
\text { pre-and postphlebotomy }\end{array}$} \\
\hline Normal Range & Prephlebotomy & Postphlebotomy \\
\hline Iron, mg/dl & $50-150$ & $90.1 \pm 14.8$ & $59.7 \pm 9.9^{*}$ \\
TIBC, mg/dl & $200-400$ & $393.6 \pm 27.6$ & $399.9 \pm 20.0$ \\
TSI, \% & $20-50$ & $25.4 \pm 4.9$ & $16.7 \pm 3.6^{\star}$ \\
\hline
\end{tabular}

TIBC: serum total iron binding capacity; TSI: transferin saturation index. ${ }^{*} p<0.05$ 

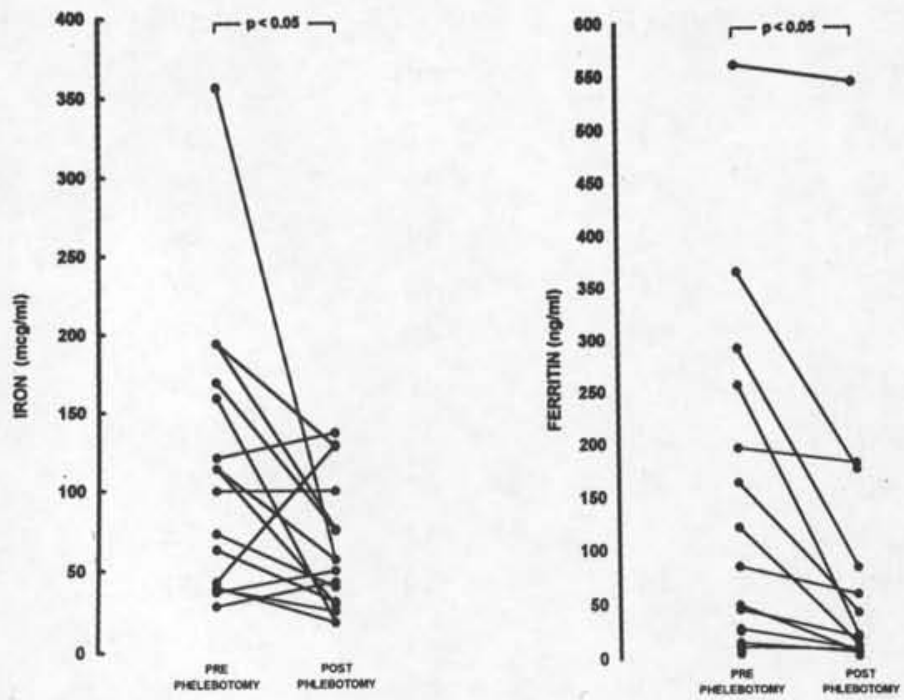

Figure 1- Iron and ferritin individual values for COPD patients submitted to sequencial phlebotomies.

platelet count, 4 of them with final measurements beyond $400,000 / \mathrm{mm}^{3}{ }^{3}$ Studies of platelet aggregation made with different stimulant agents did not show any significant postphlebotomies change.

Adequate thromboelastography studies before and after phlebotomies could not be obtained in 4 patients due to technical problems. In the 13 studied subjects, a significant decrease was noticed in $k$ during the final studies. Although $\boldsymbol{r}$ also experienced a decrease, such change did not reach statistical significance. Finally, $a$ values showed a significant postphlebotomies increase.

\section{DISCUSSION}

Phlebotomy may be used in the care of COPD patients in an attempt to reduce detrimental cardiovascular effects of blood hyperviscosity due to polycythemia. The basis for this procedure is the effect of phlebotomy in improving hemodynamic conditions and exercise performance in such patients. ${ }^{2-4.7 .8 .11-13}$ However, the effects of this kind of therapy on hemostasis and iron reserves of COPD patients had not been thoroughly examined before.

Our present results showed that the normalization of hematocrits by phlebotomies led to an important reduction in iron body contents. This became apparent by the significant decreases in serum iron, ferritin and TSI (Table
2). Serum ferritin is a good indicator of iron body stores, and the drop in its levels denotes that the tissue iron contents ${ }^{28.29}$ were also affected.

Iron deficiency states may have effects on red blood cells and solid organ tissues. Although it would be expected that iron deficiency could have an inhibitory effect on COPD hypoxic hemopoietic response, this is not always the case. Secondary polycythemia associated to iron deficiency in COPD patients has been described. ${ }^{30.31}$ Some authors report that iron depletion may not be an impeding factor to increases in red cell mass, and that in such cases polycythemia is associated with hypochromic erythrocytes. ${ }^{32}$

An iron deficiency state may also disturb the muscular oxidative metabolism, interfering with the patient's work performance. ${ }^{16}$ The tissue haem iron compounds include the cytochromes, myoglobin, catalase and peroxidase. In addition, muscles harbor non-haem iron-containing enzymes such as NADH dehydrogenase, succinic dehydrogenase and xanthine oxidase. Finally, some enzymes such as aconitase and tryptophan pyrrolase require iron or haem as a cofactor.

Experimental studies on rats have found that mild and severe iron deficiency are associated with deficits of cytochrome $\mathrm{c}$ and mioglobin in skeletal muscle. ${ }^{33} \mathrm{FINCH}$ et al. ${ }^{34}$ completed studies of work performance on irondeficient rats, keeping hemoglobin levels constant through exchange transfusions. It was seen that iron-deficient rats had a significant shorter running time than controls with similar hemoglobin levels. After 4 days of iron administration, the iron-deficient group achieved normal running times.

Biochemical analysis done at that time suggested that an increase in the rate of oxidative phosphorylation with a-glycerophosphate as a substrate played a key role in the improvement of work performance. Non-published data from our laboratory have shown small but significant increases in the maximal work load and oxygen consumption reached by 15 iron-deficient, anemic wom 4 days after administration of IV iron-dextran, even though their hemoglobin levels had not changed.

Therefore, we can hypothesize that COPD patients who show amelioration of exercise performance after phlebotomies might have this effect attenuated if simultaneous iron deficiency states develop. The 
Table 3

Results of coagulation studies (Mean \pm SE) obtained pre-and postphlebotomy

\begin{tabular}{lccc}
\hline & Normal Range & Prephlebotomy & Postphlebotomy \\
APTT & $0.90-1.25$ & $1.14 \pm 0.06$ & $1.06 \pm 0.04$ \\
Fibrinogen, mg/dl & $200-400$ & $262 \pm 12$ & $236.5 \pm 13.2$ \\
Platelets/mm ${ }^{3}$ & $200,000-400,000$ & $227,300 \pm 13,900$ & $312,500 \pm 30.2^{\star}$ \\
Platelet Aggregation & & & \\
ADP 3mM, \% & $60-80$ & $65.8 \pm 5.1$ & $74.1 \pm 3.9$ \\
ADP 1mM, \% & $60-80$ & $63.0 \pm 6.4$ & $69.8 \pm 4.7$ \\
Epinephrine, \% & $60-80$ & $63.3 \pm 6.4$ & $64.6 \pm 5.9$ \\
Collagen, \% & $60-80$ & $80.0 \pm 2.8$ & $78.2 \pm 3.2$ \\
Thromboelastography" & & & \\
$\boldsymbol{r}$, mm & $7.2-9.6$ & $9.9 \pm 0.7$ & $9.0 \pm 0.5$ \\
$\boldsymbol{k}, \mathrm{mm}$ & $5.8-7.8$ & $7.5 \pm 0.7$ & $4.5 \pm 0.3^{\star}$ \\
$\boldsymbol{a}, \mathrm{mm}$ & $48-60$ & $53.6 \pm 1.4$ & $60.4 \pm 1.1^{*}$ \\
\hline
\end{tabular}

APTT: activated partial thromboplastin time; ADP: adenosine diphosphate; $r$. reaction time;

$\boldsymbol{k}$. coagulation time; $\boldsymbol{a}$ : maximum clot amplitude

${ }^{*} \mathrm{p}<0.05$; \# data from 13 patients

development of hypochromic red cells in such situations could impair oxygen transport to the tissues, even with the presence of a high hematocrit. Furthermore, iron depletion at the skeletal muscle level could lead to poor enzymatic function and oxygen utilization.

In order to evaluate the effects of Hct correction by phlebotomies on the hemostasis of COPD polycythemic patients, tests were done to assess the intrinsic pathway, platelet and fibrinogen concentrations, platelet aggregation and TEG. A renewed interest in TEG monitoring has been seen recently because its tracing represents the shear elasticity of a blood clot as it forms, matures, retracts and eventually lyses. This test is extremely sensitive to identify hypercoagulability. ${ }^{27}$

The initial evaluation prephlebotomy did not show any evidence of hypercoagulability, since most of the test results were within the normal range for our coagulation laboratory (Table 3 ). The only exception was the reaction time $r$, which represents the time required for initial fibrin formation, which was slightly increased. This last finding indeed is more compatible with a hypocoagulability condition.

The mean platelet count increased significantly after phlebotomy from 227,300 to $312,500 \mathrm{~mm}^{3}$ (Table 3 ). Increases in platelet number have been reported after chronic and acute blood loss. ${ }^{35.36}$ The mechanisms involved in such rises may be related to iron depletion, since an inhibitory effect of this metal in throbopoiesis has been described.$^{35}$ Other studies suggest the presence of an humoral factor, the thrombopoietin, in plasma from animals with posthemorrhagic thrombocytosis. ${ }^{37}$

In opposition to previous reports on COPD patients, we did not observe an increase in platelet aggregation after phlebotomy. ${ }^{18.38-40}$ Those reports attempted to relate their findings to increases in circulating cathecolamines, especially serotonin, secondary to the bleeding. The differences between present and former results may be explained by the fact that our blood samples were collected later, around one week after the last phlebotomy, when normalization of cathecolamine levels probably had already occurred.

Other significant postphlebotomy changes were an extension of $\boldsymbol{a}$ and shortening of $\boldsymbol{k}$ in the TEG tracings (Table 3 ). The parameter $\boldsymbol{a}$ represents the maximum clot strength. The parameter $k$ represents the speed of clot formation, fibrin crosslinking and platelet-fibrin interaction. Both parameters may be decreased in cases of thrombocytopenia or hypofibrinogenemia. Although with no statistical significance, the $\boldsymbol{r}$ value also decreased postphlebotomy.

These last results suggest that improvements in thrombin formation have occurred postphlebotomy. This could be a non-specific reaction to bleeding, as increases in coagulation activity measured by TGE following blood 
losses during surgery have been described ${ }^{41}$ Such changes were documented even 2 hours after surgery and could have accounted for cathecolamine releases related to stress, and the entry into circulation of coagulation factors from the hepatic interstitial fluid. However, our final coagulation tests were performed about 7 days after the last phlebotomy, again making this interpretation less probable. Another possibility is that decreased hematocrits led to falls in viscosity with better liver perfusion and oxygenation, promoting improvement its production of coagulation factors.

The increase in $a$ may also be related to the enlargement of the platelet counting. Although the fibrinogen levels have not changed, the growth in $a$ postphlebotomy may also be in part secondary to a higher availability of fibrinogen for the fibrin network making. In high Hct samples, the total amount of fibrinogen may not be enough to make a fibrin network capable of strongly containing an increased number of red cells. Low Hct samples may have proportionally more fibrinogen to be used in the fibrin network, producing clots with greater texture.

In summary, the coagulation tests made after phlebotomy have shown small changes towards an augmented coagulability. Such changes could be the result of an organic reaction to bleeding, especially the increase in platelet counting. Although the precise clinical meaning of these findings are unknown, the literature contains a reference to a patient with pulmonary artery thrombosis following phlebotomies. ${ }^{42}$ However, among the different tests done, only $k$ reached a final value out of our normal laboratory range. Therefore, we speculate that the detected changes do not represent a harmful thrombotic risk related to the phlebotomies

Based in the present results, we do not think the prophylactic administration of anticoagulant agents after phlebotomies in COPD patients is necessary. In addition, we recommend oral iron supplementation after phlebotomies for polycythemic COPD patients in order to avoid iron deficiency.

\section{RESUMO}

Determinar os efeitos das sangrias nas reservas corporais de ferro e em testes da coagulação sanguínea de pacientes com policitemia secundária a hipoxemia por doença pulmonar obstrutiva crōnica (DPOC). Dezesete pacientes portadores de DPOC, com hematócritos superiores a $54 \%$, (Hct médio: $57 \pm 0,49 \%$ ) que não tinham feito uso recente de agentes antinflamatórios ou antiadesivos plaquetários, e cujo volume expirado forçado no primeiro segundo (VEF,), médio foi de $0,92 \pm 0,11 \mathrm{~L}$. Determinaçāo dos niveis de ferro, ferritina, capacidade de ligaçāo do ferro, indice de saturaçāo da transferrina, fibrinogênio, tempo de tromboplastina parcial ativada, número de plaquetas, agregação plaquetária e de parâmetros da coagulaçāo medidos pela tromboelastografia. Tais dosagens foram realizadas antes e em torno de sete dias após a normalização dos hematócritos através de sangrias de $300-400 \mathrm{ml}$ cada, realizadas em dias alternados, resultando num número médio de 4,4 sangrias por paciente. Com as sangrias os níveis séricos do ferro cairam de $90,1 \pm 14,8 \mathrm{mg} / \mathrm{dl}$ a $59.7 \pm 9.9 \mathrm{mg} / \mathrm{dl}$, e os niveis da ferritina sérica de $133,8 \pm 37,9 \mathrm{ng} / \mathrm{ml}$ a $70,8 \pm 32,7 \mathrm{ng} / \mathrm{ml}(p<0.05)$. Em relação aos estudos da coagulaçăo, houve um aumento significante na contagem plaquetảria de $227.300 \pm 13.900$ a $312.500 \pm 30,200$ elementos $/ \mathrm{mm}^{3}$, e na amplitude máxima do coágulo obtida pela tromboelastografia (a), de $53,6 \pm 1,4 \%$ para $60,41 \pm 1,1 \%$. O tempo de coagulação (k) da tromboelastografia, também diminuiu significantemente de $7.5 \pm 0,7 \mathrm{~mm}$ pré-flebotomias para $4,5 \pm 0,3 \mathrm{~mm}$ pós-flebotomias. Os autores concluem que embora as alteraçōes da coagulaçāo tenham sido de pequena monta, os decréscimos nas reservas de ferro foram significantes podendo ter implicaçöes clinicas importantes. 


\section{REFERENCES}

1. Kingler JR, Hill NS. Right ventricular dysfunction in chronic obstructive pulmonary disease. Chest 1991;99:715-23.

2. Harrison BDW, Gregory RJ, Clark TJH, Scott BW. Exchange transfusion with Dextran 40 in polycythaemia secondary to hypoxic lung disease. Br Med J 1971;4:7136.

3. Harrison BDW, Daws J, Madgwick RG, Evans M. The effects of therapeutic decrease in packed cell volume on the responses to exercise of patients with polycythaemia secondary to lung disease. Clin Sci 1973;45:833-47.

4. Wedzicha JA, Rudd RM, Apps MCP, Cotter FE, Newland AC, Empey DW. Erythrapheresis in patients with polycythaemia secondary to hypoxic lung disease. Br Med J 1983;286:511-4.

5. Dayton LM, McCullough RE, Scheinhorn DJ, Well JV. Symptomatic and pulmonary response to acute phlebotomy in secondary polycythemia. Chest 1975;68:785-90.

6. Bornstein R, Meron D, York E, Sproule B, Zak C. Effects of venesection on cerebral function in chronic lung disease. Can J Neurol Sci 1980;7:293-6.

7. Chetty KG, Brown SE, Light RW. Improved exercise tolerance of the polycythemic lung patient following phlebotomy. Am J Med 1983;74:415-20.

8. Chetty KG, Light RW, Stansbury DW, Milne N. Exercise performance of polycythemic chronic obstructive pulmonary disease: Effect of phlebotomies. Chest 1990;98:1073-7.

9. Massaro D, Katz F. Effect of venesection on arterial gas values and ventilatory function in patients with chronic bronchitis. Thorax 1965;20:441-6.

10. Patakas DA, Christaki PI, Louridas GE, Sproule BJ. Control of breathing in patients with chronic obstructive lung disease and secondary polycythemia after venesection. Respiration 1986;49:257-62.

11. Rakita L, Gillespie DG, Sancetta SM. The acute and chronic effects of phlebotomy on general hemodynamics and pulmonary functions of patients with pulmonary emphysema. Am Heart J 1965;70:466-75.

12. Segel N, Bishop JM. The circulation in patients with chronic bronchitis and emphysema at rest and during exercise, with special reference to the influence of changes in blood viscosity and blood volume on the pulmonary circulation. J Clin Invest 1966;45:1555-68.

13. Weisse AB, Moschos CB, Frank MJ, Levinson GE, Cannila JE, Regan TJ. Hemodynamic effects of staged hematocrit reduction in patients with stable cor pulmonale and severel elevated hematocrit levels. Am J Med 1975;58:92-8.

14. Lieden G. Iron state in regular blood donors. Scand J Haematol-1973;11:342-9.

15. Propper R, Nathan D. Clinical removal of iron. Ann Rev Med 1982;33:509-19.

16. Dallman PR. Manifestations of iron deficiency. Semin Hematol 1982;19:19-30.
17. Schafer AL. The hypercoagulable states. Ann Intern Med 1985;102:814-28.

18. Cordova C, Musca A, Violi F, Perrone F, Alessandri C, Marigliano V, Balsano F. Pathophysiological and clinical research on the platelet hyperaggregation in patients with chronic respiratory failure. Bull Europ Physiopatol Respir 1980;16:113-5.

19. Mitchell RS, Silvers G, Dart GA, Petty TL, Vicent TN, Ryan SF, Filley GF. Clinical and morphologic correlations in chronic airway obstruction. Am Rev Respir Dis 1968;97:5462.

20. Ryan SF. Pulmonary embolism and thrombosis in chronic obstructive emphysema. Am J Pathol 1963;43:767-73.

21. Balsano F, Cordova C, Musca A, Perone A, Violi F. Ruolo del metabolismo pulmonary sull'emocoagulazione in fisiologia in clinica ed in terapia. Cl Terap 1977;80:513-7.

22. Brun J, Biot N, Perryn-Fayolle M, Sab H. Les troubles de la coagulation sanguine au cours de l'insuffisance respiratoire cronique: Deductions therapeutiques. Poumon Couer 1962;18:181-194.

23. Gaida A, Ghio G. Emocoagulazione e fibrinolisi nell'enfisema polmonare. Minerva Med 1964;55:2122-5.

24. Chanarin I. Laboratory haematology: an account of laboratory techniques, 1st ed. Edinburgh: Churchill Livingstone, 1989:274-5.

25. Ratnoff OD, Menzie C. A new method for determination of fibrinogen in small samples of plasma. J Lab Clin Med 1951;37:316-20.

26. Born GVR. Aggregation of blood platelets by adenosine diphosphate and its reversal. Nature 1962;194:327-9.

27. Spiess BD, Davalle M. Coagulation monitoring in the surgical intensive care unit. Crit Care Clin 1988;4:605-20.

28. Milnan N, Pedersen NS, Visfeldt J. Serum ferritin in healthy Danes: Relation to marrow haemosiderin iron stores. Dan Med Bull 1983;30:116-20.

29. Walters GO, Miller FE, Worwood M. Serum ferritin concentration and iron stores in normal subjects. J Clin Path 1973;26:770-2.

30. Tura S, Pollycove M, Gelpi AP. Erythrocyte and ironkinetics in patients with chronic pulmonary emphysema. J Nucl Med 1962;3:110-25.

31. Shaw DB, Simpson T. Polycythemia in emphysema. Q J Med 1961;30:135-52.

32. Stradling JR, Lane DJ. Development of secondary polycythaemia in chronic airways obstruction. Thorax 1981;36:321-5.

33. Siimes MA, Refino C, Dallman PR. Manifestations of iron deficiency at various levels of dietary iron intake. Am J Clin Nutr 1980;33:570-4.

34. Finch CA, Miller LR, Inamdar AR, Person R, Seiler K, Mackler B. Iron deficiency in the rat: Physiological and biochemical studies of muscle dysfunction. J Clin Invest 1976;58:447-53.

35. Krizsa A. Study on the development of posthaemorrhagic thrombocytosis in rats. Acta Haemat 1971;46:228-31. 
36. Karpaktin S, Garg SK, Fredman ML. Role of iron as a regulator of thrombopoiesis.Am J Med 1974;57:521-5.

37. Weintraub A, Khan I, Karpatkin S. A splenic dependent thrombopoietic factor in chronic blood loss plasma. Clin Res 1974;22:411A.

38. Cordova C, Musca A, Violi F, Alessandri A, Perrone A, Balsano F. Platelet hyperfunction in patients with chronic airways obstruction. Eur J Respir Dis 1985;66:9-12

39. Musca A, Cordova C, Violi F. The thrombogenic risk in chronic respiratory failure. Adv Exp Med Biol 1984;164:369375 .
40. Cordova C, Musca A, Perrone A, Violi F, Alessandri C, Marigliano V. Possibile ruolo della serotonina nel determinismo della iperaggregazione piastrinica dopo salasso in pazienti con insuficienza respiratoria cronica. $\mathrm{Cl}$ Terap 1979;90:489-501.

41. Tuman KJ, Spiess BD, Mc Carthy RJ, Ivankovich AD. Effects of progressive blood loss on coagulation as measures by thromboelastography. Anesth Analg 1987;66:856-63.

42. Chamberlain DA, MillardFJC. The treatment of polycythaemia secondary to hypoxic lung disease by continuous oxygen administration. Q J Med 1963;32:341-50. 